Tarih Kültür ve Sanat Araştırmaları Dergisi

Revue des Recherches en Histoire Culture et Art

مجلة البحوث التاريخية و الثقافية والفنية
Vol. 7, No. 2, June 2018

Copyright (C) Karabuk University

http://kutaksam.karabuk.edu.tr

\title{
DOI: 10.7596/taksad.v7i2.1606
}

Citation: Lipich, T., Lipich, V., Penskaya, T., Penskoy, V., Shilishpanov, R., \& Strahova, I. (2018). Early Modern Russian State, "Tsar's Discourse" and Russian Orthodox Church in the XV-XVII Centuries. Journal of History

\section{Early Modern Russian State, "Tsar's Discourse" and Russian Orthodox Church in the XV-XVII Centuries}

Tamara I. Lipich¹, Vasiliy V. Lipich², Tatiana M. Penskaya ${ }^{3}$, Vitaly V. Penskoy ${ }^{4}$, Roman V. Shilishpanov ${ }^{5}$, Irina A. Strahova ${ }^{6}$

\begin{abstract}
The article examines some special aspects of the centralized Russian state formation as the part of the Pan - European process of the early modern state formation. The researchers focus on the problem of the Tsar's discourse as on the problem of the total claims the true Orthodox monarch should comply with. The Orthodox Church took the active part in the formation of this "discourse", and the compliance with the requirements of it guaranteed to the top authority loyalty of its people and readiness to carry out its requirements. The Church gave Grand Dukes the powerful tool when applying secular practices of legitimation.
\end{abstract}

Keywords: Late Medieval Period, Early modern Period, Early Modern State, Russia, The Orthodox Church.

\footnotetext{
${ }^{1}$ Belgorod State University, 308015, Belgorod, 85 Pobedy Str. E-mail: lipich@bsu.edu.ru

2 Belgorod State University, 308015, Belgorod, 85 Pobedy Str.

${ }^{3}$ Belgorod State University, 308015, Belgorod, 85 Pobedy Str.

${ }^{4}$ Belgorod State University, 308015, Belgorod, 85 Pobedy Str.

${ }^{5}$ Belgorod State University, 308015, Belgorod, 85 Pobedy Str.

${ }^{6}$ Belgorod State University, 308015, Belgorod, 85 Pobedy Str.
} 


\section{Introduction}

The second half of the 15th - the middle of the 16th centuries is the time when long process of formation of the early modern Russian State comes to the end. In the Russian historical literature behind it stands the name "centralized", though in recent years among historians both in Russia, and beyond it, doubts concerning this term in relation to realities of the late Middle Ages of early modern times as far as it was "centralized" were strongly expressed, however, this topic should not be closed before our point on real changes in political, administrative, judicial and ideological spheres of life of early modern society and the state is shown - no matter Russian, French, Spanish or any other state be concerned.

These changes promoted change in appearance, and internal structure of the early modern states, and these changes had gradual, evolutionary character, dragging on for quite long time. This evolutionary character is perhaps, one of the most important and characteristic features of these political educations founding. The gradualness, some kind of "obscurity" of changes guaranteed a certain continuity, a perpetuality of political, administrative and legal traditions [See, for example: $1 ; 2$ ]. In view of thinking conservatism in society at that time, its suspicious attitude towards unexpected, sharp steps, breaking off the habitual course of life, such slow scenario of unfolding guaranteed (to a certain extent) lack of "great shocks" and, finally, promoted reconciliation of society with gradually growing ripe innovations.

An important role in these processes was played by an ideological factor, ideological justification, legitimation of these gradual changes [See, for example: 3]. In realities of that time this function was assigned to religion and those social and political institutes which served it and acted as carriers of its values and ideologems. In early modern Russia this role was carried out by the Russian Orthodox Church providing formation and correct functioning of Tsar's Discourse without which correct functioning of the weak, insufficiently developed state machinery would be extremely complicated, if at all perhaps.

\section{Methodology}

Analyzing the forming features of the "centralized" Russian state in the second half of the XV-XVI centuries, we recognized that its "centrality" was rather a certain desirable purpose, but not political, legal and the more so economic reality of that time, and it was characteristic not only of Russia, but also other early modern states. In general we agree with opinion of the American historian N. Kollmann that characterizing features of a political and legal regime of the Russian state during an era of early modern times, she specified that its "state-building experience was part of a broader early modern continuum of change" that "Russia's centralization can be seen in a continuum of normal early modern state-building" in itself [3, p.1]. In general, the same "continuum" keeps within a framework, even taking into consideration local regional differences, the "composite state" model offered by the British historians G. Kenigsberger and J. Elliot [4;5].

Owing to the administrative weakness and some other, the reasons new political, administrative, judicial, legal and other practices could not approve early modern monarchy quickly and effectively, force them to function effectively and were forced to be reconciled with preservation of a set of remnants of "old times". The new order was spread gradually, from above, by means of several "strategy". It is possible to carry "addin" over old, traditional administrative structures. Second "strategy" assumed flirting of the supreme power with local political elite, seeking to keep their loyalty by means of preservation of a considerable part of their "liberties" and attraction to government both on local, and on central levels. As result, "composite monarchies were built on a mutual compact between the crown and the ruling class of their different provinces which gave even the most arbitrary and artificial of unions a certain stability and resilience" [5, p.57]. 
So, key situation in this quote - "mutual consent between a crown and ruling elite". However, when we speak about local elite, we should not forget that it is not only about secular elite, but it is always necessary to remember also that early modern society in many respects remained (especially in the mental sphere) society medieval, and the religion played in his lives, and not only spiritual, but also political and legal, very essential role. From here third "strategy" which essence N. Kollmann in relation to such "empires" (understanding as them the multinational states including territories with the different level of social and economic, political and cultural development) as Habsburg, Ottoman or Russian, defined as the aspiration of the Supreme power to strengthen the legitimacy, to guarantee loyalty of the subject population through active application of ritual, ideological and symbolical "discourses" [3, p.21].

The American historian described this "discourse" in the following categories: "The ruler provided justice, protected his people from harm and patronized the church" [3, p.21] and, developing the thesis further, shows as it worked, on examples of the Moscow city revolts of the 17th century. The sovereign had to correspond to an image of fair, pious, truly orthodox tsar, and this compliance gave it additional legitimation: "His (the tsar) legitimacy depended upon his acting on that authority", and that "the relationship of violence, autocracy and ideology in Muscovy is profound: precisely because the tsar was good, pious and benevolent - not a tyrant, not a despot - he was required to respond to his people" [3, pp.401-402].

From that how Moscow sovereign and his actions corresponded to the criteria of Tsar's Discourse occurring in society, his authority, his influence, his life and the fate of its dynasty depended, at last. The fate of Boris Godunov and his son Fedor and also False Dmitry I, who tried to be beyond this model, make a striking example. But for this "discourse", first of all, the Russian Orthodox Church in the person of its administrative and intellectual elite was a creator.

The Supreme power was forced to consider a position of Church, making these or those decisions both in external, and in domestic policy because church hierarches made a part of ruling elite of the Russian land integral (for a long time) with which opinion the Supreme power could not but reckon. Therefore, studying the processes connected about formation of the "centralized" Russian state, development and distribution new political, administrative, judicial, legal and others practices, we cannot but take into consideration a position of Church and degree (and character) its participations in development of these practices. Churches, both ideological (first of all), and technical (ensuring literacy anyway, but was in hands of Church) and other support these practices could not but take place, function properly.

\section{Results and Discussion}

Considering interaction of the Supreme power and church in Russia in the context of formation of the early modern state and institutes, characteristic of it, and the practices, first of all we will note that cooperation of the prince as secular lord and metropolitan as lords spiritual had old and strong roots. The fact that medieval Russian scribes, modeling character of the relations between the Supreme secular and spiritual authorities, proceeded from the known Byzantine symphonies model as cooperation of two authorities in achievement of the uniform purpose - to preservation of the orthodox world, an orthodox "terrestrial hail" and creation of necessary conditions for final rescue "communities true" does not raise doubts. It is natural that this "doctrine" carried to a certain extent informal, unwritten character and was not accurately and it is unambiguously recorded in any acts charters which are officially certified by the Supreme power (like a notorious "Great charter of liberties").

However the lack of such charter did not mean at all that the power could neglect opinion of Church and its hierarches not take into account their position in these or those questions. Moral and ideological support of Church always meant to the Supreme power very much and a lot of things, and whether taking these or 
those actions in the sphere external, whether internal policy, the power sought to get such support. For the sake of it the Supreme power could even go for rough intervention in internal affairs of Church, despite of the fact that such steps could cause a certain tension in the relations with it. The church, in turn, believed possible to make impact on the Supreme power and to insist on cancellation of these or those decisions if it believed its certain actions inappropriate to Orthodoxy canons. And it if not to speak about the right of so-called "pechalovaniye" (scolding) according to which the highest hierarches of Church could stand up for disgraced and undergone punishment from the Supreme power.

Examples of such interaction, it is possible to bring much. So, at a boundary of the 70th - the 80th of the 14th century the attempt of the grand duke Dmitry Ivanovich needing support of Church at the time of strain of relations with the Horde and Lithuania to put on metropolitan department of the candidate led to the serious conflict between it and the metropolitan Kiprian. Later nearly fifty years the firm position of the metropolitan Photius who supported the right of the grandson Dmitry Ivanovich for the Moscow table cooled passions and prevented (at least for a while) ready to burst just about internal quarreling. The church played a significant role legitimations of process of release of the Russian state from the Horde dependence, and subsequently - legitimations of conquest of Tatar "yurt" - the states of the Volga region and Siberia which arose after disintegration of the Golden Horde.

These and other similar incidents should not cover, however, before our look more important contribution which made Church in formation of the "centralized" Russian state. It is about notorious Tsar's Discourse that which we mentioned before and which played important if not defining role in legitimation of the Supreme power at this turning point of the Russian history.

Concerning this "discourse", the Russian historian I.B. Mikhaylova noted that "in the XV-XVI centuries the Russian scribes on the basis of a wide range of written sources, early Christian, Byzantine and domestic monuments taking into account traditional representations of contemporaries, developed the doctrine about the Moscow orthodox kingdom led by Christ's protégé which had a body of the mortal person and in it divine soul". Let's note, by the way, that representations of contemporaries played extremely important role because that text base on the basis of which Tsar's Discourse was developed in Russia was significantly already, than in the same Byzantium. It is connected with features of broadcasting and reception of the Byzantine cultural religious heritage in Russia when initially the volume of information transferred to newly converted Christians from "Greeks" was significantly limited.

"After the Byzantine thinkers, - the historian continued further the thought, - they (the Russian medieval intellectuals - the Bus) urged the sovereign to imitate God, to improve God the virtues granted to him, exercising the extensive power, to try to obtain prosperity of the Russian power, it is fair to operate it and it is reliable to protect it from external and internal enemies" [6, p.19]. At the same time the Church conferred responsibility not only for the acts, but also for acts and sins of the citizens on the sovereign. In this plan some kind of "best-seller" of the Russian books of the late Middle Ages - the "Punishment" (meaning "lecture, order") attributed to the Tver bishop Simeon is submitted very curious (died in 1289).

This text is remarkable the fact that in it the thesis concerning responsibility of the prince for acts of the administrators is accurately checked. On a question of the prince where to stay to the unjust princely trustee, the bishop replied that in the same place where also to his mister. "Why?" - the prince was surprised, and Simeon explained to him in what business. If the prince, the hierarch said, he is kind, godfearing, loves the truth and people favors, then and he by all means will elect the trustee same, is a match for himself - the husband God-fearing and just, fair and kind to people, reasonable and operating people subject to it agrees God's to precepts. And when the time comes to appear to the prince and his trustee before the Highest Judge, both of them by right will deserve the place in paradise. In an opposite case if the prince has no fear of the Lord, the citizens do not favor, oppresses orphans and widows and to crown it all 
appoints the trustee of the husband of the evil who finds only one princely income, without thinking of justice, then to both, both the prince, and the trustee one road - to hell [7, p.376].

The thesis about responsibility of the prince for actions of his administrators is not less accurately checked, for example, and in the writing by famous Joseph of Volotsk. Addressing the grand duke (Ivan III), the Saint specified that the Lord allocated him, the prince; the great power in order that he firmly adhered to laws and fought against any lawlessness. In your care, Josef said, addressing the prince, care about corporal wellbeing of citizens, meaning fight against robberies, murders, any attempts at property, honor and advantage and, by itself, with wrong court, "lie" [8, pp.183-184.].

On the same position firmly there was also Maximus the Greek. In one of the compositions it, comparing the sovereign to the sun, wrote that just as the sun lights with the beams and warms the world around, and the soul of the grand duke executed mildness, generosity, purity and the truth lights, decorates and on commission of good deeds moves the citizens. On the contrary, if the sovereign leads an unseemly life if his soul is overcome by rage, anger and passions other similar unseemly to an imperial rank, then and all the rest will also be dulled, will fall into a mutiny and violence [9, pp.164-165].

That the Supreme power seriously perceived such addresses is shown by one very indicative example. In 1479/80 the grand duke "brought together" from Velikiye Luki the deputy prince Ivan Lyko Obolensky, and Luciana, having exercised the right, asked humbly on the former deputy, having accused him and his people of all abuses and usury made in Lukovy and suburbs. The investigation held by order of Ivan III confirmed the facts stated in the petition, and the grand duke ordered to Lyko to Obolensky to indemnify the caused damage and to pay all court costs and other. When the former deputy offended in the best feelings drove off to the brother of the grand duke prince Boris Vasilyevich, Ivan did not stop breaking the contract with the specific prince to punish responsible though Lyko Obolensky after departure formally was subject to jurisdiction of the specific prince. Other, not less indicative example took place in the winter of 1557 . The prince M.V. Glinsky with a host, going to be at war on a monarchic order Livonia, assumed that on the road his soldiers made excesses and robberies. Victims of their actions residents of Pskov asked humbly Ivan the Terrible that punished guilty persons and indemnified the caused loss. And again, as well as in the previous case, the made investigation confirmed the facts of robberies and violence, the prince Glinsky got to disgrace, and residents of Pskov received compensation [10, p.86].

Attracts attention and other requirement of Joseph of Volotsk - the requirement be peeped about spiritual health of the citizens. In it the aged man Filofey, the author of the well-known message to Vasily III in whom the idea that Moscow is the III Rome was formulated is solidary, for example. He also pointed that fight against heretics by all means belongs to duties of the grand duke [11, p.359].

Not less if, also other duty which was imposed on the sovereign by the Russian scribes - protection, defense of small these from foreign, protection of orthodox belief and church against gentiles was no more important. Two Rome fell, the aged man Filofey, and the third taught Vasily III, Moscow, stands, the fourth not to happen. And therefore, it continued, extremely responsible and at the same time heavy burden and a duty of preservation of the last true Christian kingdom is assigned to shoulders of the orthodox sovereign. This motive is well looked through in the message of the Rostov archbishop Vassian to Ivan III, written in the fall of 1480 when on the Ugra River in opposition of the Russian and Tatar army the destiny was decided - to be or not to be Russian to the state and further depending on the Horde. Vassian wrote the grand duke, calling him for hardness. Your debt as good shepherd, he wrote, to protect the herd handed to it by the Lord from "the future wolf", warning at the same time it that if the prince is frightened of the duty assigned to it and will evade from opposition, then the Lord will ask it on all severity for the killed incorrect Christians, the destroyed and profaned temples and monasteries. Where, did the bishop exclaim, you will be able to sit on a throne again if you ruin handed to you became? 
The requirement to the sovereign as to the defender of belief and "right" messages in a series which issued from the pen of the Russian orthodox hierarches during the Kazan war of 1545-1552 - the metropolitan Makari and the Novgorod archbishop Feodosiy [12] is even more brightly and visually checked.

\section{Conclusion}

Summing up the general result of all aforesaid, we will note that to correspond to an image of the valid pious, truly orthodox monarch, the Russian sovereign needed to be followed carefully unwritten, but from that to the code of behavior which was not becoming less obligatory. The principles of this code were made by three requirements, three main functions which the true sovereign had to execute with special assiduity. What was expected from it by his citizens - it is, first, compliance to an image of the fair judge and defenders weak. This function as N. Kollmann noted, relied nearly the major: "The tsar be a pious shepherd and Old Testament judge to his people; he was supposed to protect the innocent and punish the wicked. In ideological and visual sources the tsar's role as just judge was highlighted far more than his military leadership" [3, p.26].

The second function was connected with its duties as orthodox sovereign. As by the time of completion of work on "theory" of the orthodox sovereign the Russian state remained the last independent orthodox state (The Byzantine empire and the Balkan orthodox states were already conquered by then by Turks, and in Grand Duchy of Lithuania Catholicism dominated over Orthodoxy), the Orthodox Church laid on the grand duke special hopes as on the defender of belief, the defender of Orthodoxy, the fighter against heresies and the observer of orthodox morals and morality.

The third also was directly connected with this function - the Moscow sovereign was obliged to protect by force of arms both belief, and church, and the orthodox citizens from foreigners and gentiles, not to allow repetition of the scenario of falling of the Byzantine Empire.

Only at observance of these requirements the church was ready to support actions of the grand duke and to give it necessary missing legitimacy which at that time he could not ensure in other ways. From here also the special importance of Church as one of active and major participants of creation of the early modern Russian state follows.

\section{Footnotes}

1. Pinsk, V.V. 2015. Saint or "Erbfeind gantzer christenheit"? Ivan the Terrible and his era: image and reality. Scientific result. Social and humanitarian researches. 2015. No. 3(5): 110-125. Date of the last address 03.12.2017. <http://rrhumanities.ru/media/humanities/2015/3/Penskoy_Ivan_Grozny.pdf>

Penskoy, V.V. 2015. Saint or "Erbfeind gantzer christenheit"? Ivan the Terrible and his epoch: image and reality. The research result. Publishing series: Social studies and humanities. 2015. No. 3(5): 110-125. Reference date 03.12.2017. http://rrhumanities.ru/media/humanities/2015/3/Penskoy_Ivan_Grozny.pdf

2. Pinsk, V.V. 2015. "On the on business monarchic and on territorial ...". Scientific result: Network scientific and practical magazine. It is gray. Social and humanitarian researches. 2015. T. 1, issue 4 (6). $70-$ 75: Date of the last address 03.12.2017.

<http://rrhumanities.ru/media/humanities/2015/4/Penskoy_recenziya.pdf>

Penskoy, V.V. 2015. "On his own on the matter of the Tsar and the Zemstvo..." ("On the on business monarchic and on territorial ..."). The research result. Publishing series: Social studies and humanities. 2015. $\begin{array}{llllll}\text { V1, } & \text { S. } & \text { 40-75: } & \text { 03.12.2017. }\end{array}$ http://rrhumanities.ru/media/humanities/2015/4/Penskoy_recenziya.pdf 
3. Kollmann N.S. 2012. Crime and Punishment in early modern Russia. Cambridge, Cambridge University Press: 504.

4. Koenigsberger, H. G. 1978. Monarchies and Parliaments in early modern Europe Dominium Regale or Dominium Politicum et Regale. Theory and Society. Vol. 5. 2: 191-217.

5. Elliott, J. H. 1992 A Europe of Composite Monarchies. Past \& Present. Number 137. The Cultural and Political Construction of Europe: 48-71.

6. Mikhaylova. I.B. 2010. And here all kingdoms met ... St. Petersburg. Dmitry Bulanin: 648.

Mikhaylova. I.B. 2010. And here all the kingdoms came together... (And here all kingdoms ... met) St. Petersburg. Dmitriy Bulanin: 648.

7. Izbornik. Collection of literary works of Ancient Russia (1969). M. Fiction: 627.

Selector. Ancient Rus Literature

<https://images.search.yahoo.com/search/images;_ylt=A2KLfRzVxyta6hMAKHZXNyoA;_ylu=X3oDMTByMj B0aG5zBGNvbG8DYmYxBHBvcwMxBHZOaWQDBHNIYwNzYw--

$? p=$ collection+of+works+of+literature \&fr=yfp-t> Works Collection (1969). M.

Literary publisher

<https://www.multitran.ru/c/m.exe?t=4943578_1_2\&s1=\%E8\%E7\%E4\%E0\%F2\%E5\%EB\%FC\%F1\%F2\%E2\% EE\%20\%F5\%F3\%E4\%EE\%E6\%E5\%F1\%F2\%E2\%E5\%ED\%ED\%EE\%E9\%20\%EB\%E8\%F2\%E5\%F0\%E0\%F2\%F3\%F $0 \% \mathrm{FB}>$ house: 627 .

8. Joseph of Volotsk. 2007. Messages. SPb., Academy of Sciences of the USSR publishing house: 392. Iosif Volotskiy. 2007. The Epistles. St. Petersburg,

Academy of Sciences of the USSR

<https://www.multitran.ru/c/m.exe?t=4970667_1_2\&s1=\%C0\%EA\%E0\%E4\%E5\%EC\%E8\%FF\%20\%ED\%E0 \%F3\%EA\%20\%D1\%D1\%D1\%D0> Press: 392.

9. Maximus the Greek. 1860. Compositions. T. 2. Kazan. Kazan spiritual academy: 460.

Maksim Grek. 1860. Compositions. V. 2. Kazan. Kazan theological academy: 460.

10. Pinsk V.V. 2012. Scientific sheets of the Belgorod state university. History series, Political science. Economy. Informatics. No. 13 (132). 2012. Issue 23. Belgorod: Publishing house of BELGU, 2012: 82-88.

Penskoy, V.V. 2012. Belgorod State University Scientific Bulletin. Series

History. Politology .Economics <https://www.bsu.edu.ru/bsu/science/bsu-science-journalen/list.php?SECTION_ID=6463>. Computer Science. No. 13 (132). 2012. Issue 23. BSU publishing house.

11. Sinitsyna N.V. 1998. The third Rome. Sources and evolution of the Russian medieval concept (the XV-XVI centuries). M. Indrik: 415.

Sinitsyna N.V.1998. The Third Rome. Origins and Evolution of Russian medieval concept (the XV-XVI centuries). M. Sources and evolution of the Russian medieval concept (the XV-XVI centuries). Indrik m: 415.

12. Filyushkin A.I. The diplomas of the Novgorod bishop Feodosiy devoted to the Kazan capture. Hermeneutics of Old Russian literature. Collection 10. IMLI RAS: 327-346.

Filyushkin A.I. Charters of Novgorod bishop Feodosiy of the Diploma, devoted to the capture of Kazan. Hermeneutics of the old Russian literature. Issue 10. IWL RAS: 327-346. 


\section{References}

Elliott, J. H. (1992). A Europe of Composite Monarchies. Past \& Present. Number 137. The Cultural and Political Construction of Europe: 48-71.

Filyushkin A. I. (n.d.). Charters of Novgorod bishop Feodosiy of the Diploma, devoted to the capture of Kazan. Hermeneutics of the old Russian literature. Issue 10. IWL RAS: 327-346.

Filyushkin A. I. (n.d.). The diplomas of the Novgorod bishop Feodosiy devoted to the Kazan capture. Hermeneutics of Old Russian literature. Collection 10. IMLI RAS: 327-346.

Izbornik (1969). Collection of literary works of Ancient Russia. M. Fiction: 627.

Joseph of Volotsk (2007). Messages. SPb., Academy of Sciences of the USSR publishing house: 392.

Koenigsberger, H. G. (1978). Monarchies and Parliaments in early modern Europe Dominium Regale or Dominium Politicum et Regale. Theory and Society. Vol. 5. 2: 191-217.

Kollmann N. S. (2012). Crime and Punishment in early modern Russia. Cambridge, Cambridge University Press: 504.

Maximus the Greek (1860). Compositions. T. 2. Kazan. Kazan spiritual academy: 460.

Mikhaylova. I. B. (2010). And here all kingdoms met ... St. Petersburg. Dmitry Bulanin: 648.

Penskoy, V. V. (2012). Belgorod State University Scientific Bulletin. Series History. Politology. Economics <https://www.bsu.edu.ru/bsu/science/bsu-science-journal-en/list.php?SECTION_ID=6463>.Computer Science. No. 13 (132). 2012. Issue 23. BSU publishing house.

Penskoy, V. V. (2015). "On his own on the matter of the Tsar and the Zemstvo..." ("On the on business monarchic and on territorial ..."). The research result. Publishing series: Social studies and humanities. 2015.

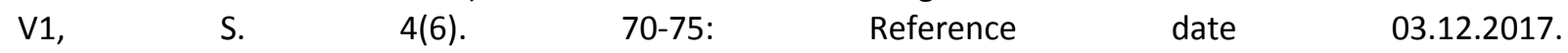
http://rrhumanities.ru/media/humanities/2015/4/Penskoy_recenziya.pdf

Pinsk V. V. (2012). Scientific sheets of the Belgorod state university. History series, Political science. Economy. Informatics. No. 13 (132). 2012. Issue 23. Belgorod: Publishing house of BELGU, 2012: 82-88.

Pinsk, V. V. (2015). "On the on business monarchic and on territorial ...". Scientific result: Network scientific and practical magazine. It is gray. Social and humanitarian researches. 2015. T. 1, issue 4 (6). 70-75: Date of the last address 03.12.2017. <http://rrhumanities.ru/media/humanities/2015/4/Penskoy_recenziya.pdf>

Pinsk, V. V. (2015). Saint or "Erbfeind gantzer christenheit"? Ivan the Terrible and his era: image and reality. Scientific result. Social and humanitarian researches. 2015. No. 3(5): 110-125. Date of the last address 03.12.2017. <http://rrhumanities.ru/media/humanities/2015/3/Penskoy_Ivan_Grozny.pdf>

Sinitsyna N. V. (1998). The Third Rome. Origins and Evolution of Russian medieval concept (the XV-XVI centuries). M. Sources and evolution of the Russian medieval concept (the XV-XVI centuries). Indrik m: 415. 